\title{
Sosialisasi pencegahan dan pengendalian Infeksi Saluran Nafas Akut di Wilayah XIII Koto Kampar
}

\author{
Rahmayati Rusnedy ${ }^{1}$, Adriani Susanty ${ }^{1}$, Rickha Octavia ${ }^{1}$, Nofri Hendri Sandi ${ }^{1}$, Ferdy Firmansyah ${ }^{1}$, \\ Armon Fernando ${ }^{1}$ \\ 1 Sekolah Tinggi Ilmu Farmasi Riau, Pekanbaru, Indonesia.
}

DOI: https://doi.org/10.29303/indra.v1i2.28

\section{Article Info}

Received : 22-07-2020

Revised : 13-08-2020

Accepted: 10-09-2020

\begin{abstract}
Acute Respiratory Infection (ARI) is one of the highest infectious diseases in Indonesia that can cause death. The public knowledge about the prevention and control of ARI is inadequate, so prevention efforts are needed to reduce the transmission of this infection disease. The purpose of this community service activity is to increase the knowledge of the people of Gunung Bungsu Village, Kec. XIII Koto Kampar on preventing the transmission of ARIs through preventive measures by providing education on how to use masks and proper ethics when coughing/sneezing. The method used was an interactive and participatory model by involving the community at Gunung Bungsu Village, Kec. XIII Koto Kampar. This socialization activity increased the community knowledge, showed by the enthusiasm of community at Gunung Bungsu Village, Kec. XIII Koto Kampar who actively interacts through the questions they ask to increase their understanding of ARI. Beside that, the results of the questionnaire assessment showed that the community was satisfy with the socialization of ARI prevention. This service can be useful for the prevention and control of ARI around the neighborhood.
\end{abstract}

Keywords: acute respiratory infections, prevention, socialization

Citation: Rusnedy, R., Susanty, A., Octavia R., Sandi, N. H., Firmansyah, F., \& Fernando, F. (2020). Sosialisasi pencegahan dan pengendalian infeksi saluran nafas akut di desa Gunung Bungsu Kec. XIII Koto Kampar. INDRA Jurnal Pengabdian kepada Masyarakat, 1(2), 20-24. doi: https://doi.org/10.29303/indra.v1i2.28

\section{Pendahuluan}

Di Indonesia masih banyak penyakit yang menjadi masalah kesehatan, salah satu diantaranya ialah penyakit infeksi (Dewi dkk, 2020). Infeksi Saluran Pernafasan Akut (ISPA) merupakan penyakit saluran pernafasan yang bersifat akut. Penyakit ini dapat disebabkan oleh berbagai sebab (multifaktorial) yang dapat disebabkan oleh virus atau bakteri, namun yang sering menyebabkan ISPA adalah virus (Sukarto dkk 2016). Meskipun organ saluran pernafasan yang terlibat adalah hidung, laring, tenggorokan, bronkus, trakea, dan paru-paru, namun yang menjadi fokus utama adalah paru-paru. Titik perhatian ini disepakati karena tingginya tingkat mortalitas radang paru-paru pada pasien ISPA (Widoyono, 2011).
Selain itu, ISPA didefinisikan sebagai infeksi saluran pernapasan akut yang disebabkan oleh agen infeksius yang ditularkan dari manusia ke manusia. Timbulnya gejala biasanya cepat, yaitu dalam waktu beberapa jam sampai beberapa hari. Gejalanya meliputi demam, batuk dan sering nyeri tenggorok, pilek, sesak napas, mengi, atau kesulitan bernapas (Masriadi, 2017).

Menurut WHO (2007), ISPA menjadi salah satu penyebab utama morbiditas dan mortalitas penyakit menular di dunia. Hampir empat juta orang meninggal akibat ISPA setiap tahun, 98\% diantaranya disebabkan oleh infeksi saluran pernapasan bawah. Kelompok yang paling berisiko adalah balita, anak-anak, dan orang lanjut usia, terutama di negara-negara dengan pendapatan per kapita rendah dan menengah. 
ISPA merupakan penyakit yang banyak terjadi di negara berkembang serta salah satu penyebab kunjungan pasien ke puskesmas (40\%-60\%) dan rumah sakit (15\%-30\%). Kasus ISPA terbanyak terjadi di India 43 juta kasus, China 21 kasus, Pakistan 10 juta kasus dan Bangladesh, Indonesia, Nigeria masingmasing 6 juta kasus. Semua kasus ISPA yang terjadi di masyarakat, $7-13 \%$ merupakan kasus berat dan memerlukan perawatan rumah sakit (Dirjen PP \& PL, 2011). Kasus ISPA di Indonesia berada pada daftar 10 penyakit terbanyak di rumah sakit (Kemenkes RI, 2012). Penyakit ini lebih banyak dialami pada kelompok penduduk kondisi ekonomi menengah ke bawah (Kemenkes, 2013).

Penyakit ISPA masih menjadi masalah kesehatan masyarakat karena dampak yang ditimbulkan sangat besar terhadap penderita tidak hanya pada anak-anak tetapi juga orang dewasa. Penyakit ISPA juga dapat menjadi pemicu dari penyakit-penyakit lainnya dan berkembang menjadi penyakit yang berbahaya seperti pneumonia bahkan dapat menimbulkan kematia. Selain itu, ISPA cukup membuat perhatian, penyakit tersebut merupakan penyakit menular yang risikonya dipengaruhi oleh faktor ekstrinsik salah satunya yaitu lingkungan dimana kondisi lingkungan yang buruk seperti polusi udara dapat meningkatkan faktor risiko terjadinya ISPA (Depkes, 2009). Kondisi lingkungan tempat tinggal yang memiliki ventilasi dan penyinaran yang cukup di siang hari, lingkungan luar dan dalam rumah yang bersih akan menurunkan resiko infeksi saluran pernapasan akut (Maryunani, 2012). Selain itu, faktor resiko juga dapat diupayakan adalah tindakan pencegahan yang rutin dilakukan seperti mencuci tangan, menggunakan masker wajah, dan sarung tangan (Caruso dan Gwaltney, 2005).

Pengendalian penyakit ISPA memerlukan upaya promosi kesehatan untuk meningkatkan kemampuan masyarakat agar hidup sehat dan mampu mengembangkan kesehatan serta terciptanya lingkungan yang kondusif. Peran promosi kesehatan tersebut merupakan tugas dari pihak tenaga kesehatan. Oleh sebab itu, dinilai sangat perlu melakukan kegiatan pengabdian masyarakat mengenai upaya promosi kesehatan dalam sosialisasi Pencegahan dan Pengendalaian Infeksi Saluran Nafas Akut (ISPA) di Desa Gunung Bungsu Kecamatan XIII KOTO KAMPAR. Tujuan dari kegiatan sosialisasi ini adalah untuk meningkatkan pengetahuan masyarakat Desa Gunung Bungsu Kec. XIII Koto Kampar terhadap pencegahan dan pengendalian penyebaran ISPA melalui upaya tindakan preventif dengan harapan mampu menerapkan dan mendampingi masyarakat lainnya terutama tentang bagaimana upaya mengetahui gejala sebagai bentuk deteksi dini jangkitan penyakit ISPA agar dapat segera ditangani dengan tepat dan mencegah penularan yang mungkin terjadi.

\section{Metode}

Penerapan kegiatan ini dilakukan dengan kolaborasi antara 6 orang dosen dan mahasiswa STIFAR RIAU kepada masyarakat Desa Gunung Bungsu, Kec. XIII Koto Kampar. Sosialisasi ini menggunakan metode interaktif dan partisipatif melalui pemaparan materi terlebih dahulu dan dilanjutkan sesi diskusi tanya jawab mengenai infeksi Saluran Nafas Akut (ISPA) dan infeksi pada saluran nafas yang disebabkan oleh SARS-CoV-2 Virus.

Kemudian dilanjutkan partisipasi langsung masyarakat untuk mempraktekkan cara menggunakan masker yang benar dan cara mencuci tangan yang benar. Pada sosialisasi ini juga dilakukan penilaian tingkat kepuasan masyarakat terhadap sosialisasi yang telah dilaksanakan dengan menggunakan metode kuisioner kepada semua masyarakat yang didata hadir sesuai form kuisioner berikut ini (Gambar 1).

\begin{tabular}{|c|c|c|c|c|}
\hline \multicolumn{5}{|c|}{ KUISIONER KEPUASAN MASYARAKAT } \\
\hline \multicolumn{5}{|c|}{$\begin{array}{l}\text { Persepsi masyarakat terhadap informasi yang diperoleh mengenai } \\
\text { Infeksi Saluran Nafas Atas (ISPA) pada pelaksanaan Pengabdian } \\
\text { Masyarakat di Desa Gunung Bungsu, Kec. XIII KOTO KAMPAR } \\
(29 / 02 / 2020) \text {. }\end{array}$} \\
\hline Nama & \multirow{2}{*}{\multicolumn{4}{|c|}{$(L / P)$}} \\
\hline Umur & & & & \\
\hline \multicolumn{5}{|c|}{ Pekerjaan } \\
\hline \multirow[t]{2}{*}{ No } & \multirow[t]{2}{*}{ Jenis pelayanan/ penyuluhan } & $\begin{array}{l}\text { Sangat } \\
\text { Puas }\end{array}$ & Puas & $\begin{array}{l}\text { Tidak } \\
\text { Puas }\end{array}$ \\
\hline & & 3 & 2 & 1 \\
\hline 1 & $\begin{array}{l}\text { Kejelasan apoteker/farmasis memberikan } \\
\text { informasi mengenai ISPA (cara } \\
\text { pencegahan dan pertolongan pertama) }\end{array}$ & & & \\
\hline 2 & $\begin{array}{l}\text { Kejelasan apoteker/farmasis memberikan } \\
\text { penyuluhan mengenai Cara menggunakan } \\
\text { masker yang benar dan Etika ketika batuk } \\
\text { atau bersin }\end{array}$ & & & \\
\hline 3 & $\begin{array}{l}\text { Ketersediaan Pamflet dan poster Sebagai } \\
\text { media informasi }\end{array}$ & & & \\
\hline \multicolumn{5}{|c|}{ SKOR TOTAL: } \\
\hline Saran & & & & \\
\hline
\end{tabular}

Gambar 1. Lembaran kuisioner penilaian tingkat kepuasan masyarakat

\section{Hasil dan Pembahasan}

Kegiatan pengabdian masyarakat di Desa Gunung Bungsu, Kec. XIII Koto Kampar yang telah dilaksanakan di Aula Puskesmas Gunung Bungsu pada tanggal 29 Februari 2020 dalam bentuk sosialisasi edukasi secara interaktif mengenai Infeksi Saluran Nafas Akut (ISPA) dan Infeksi pada saluran nafas yang disebabkan oleh CORONA Virus (Gambar 2). 


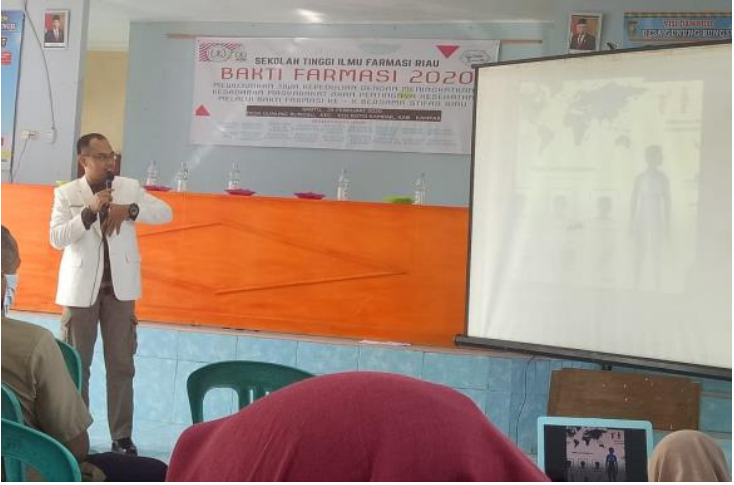

Gambar 2. Kegiatan sosialisasi Infeksi Saluran Nafas Akut (ISPA)

Kegiatan sosialisasi ini dilakukan oleh beberapa orang dosen STIFAR RIAU dan perwakilan Mahasiswa angkatan 2020 yang berkoordinasi dengan kader puskesmas di desa setempat. Pelaksanaan kegiatan berlangsung selama 3 jam dari pukul 08.00 hingga 12.00 WIB. Peserta sosialisasi mendapatkan pamflet (Gambar 3) yang memuat informasi mengenai ISPA agar dapat lebih memahami tentang gejala, cara pencegahan dan pertolongan pertama yang dapat dilakukan untuk mencegah dan mengendalikan ISPA di lingkungan tempat tinggalnya.

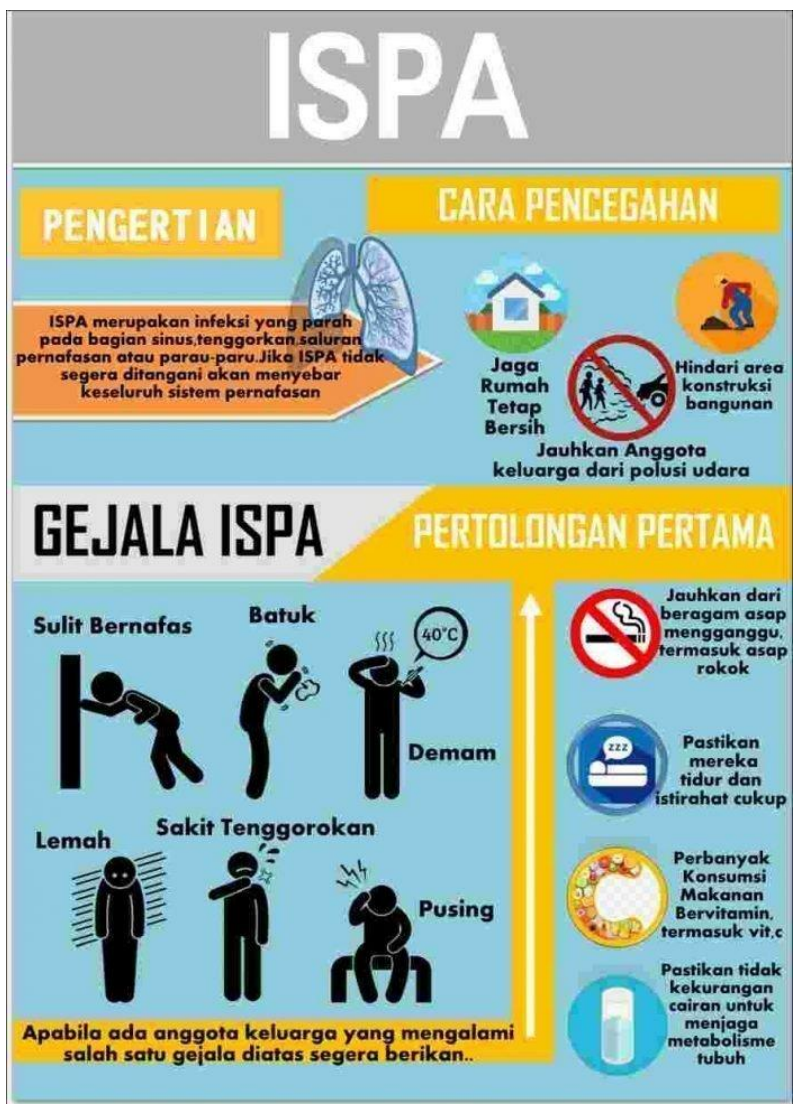

Gambar 3. Pamflet Sosialisasi ISPA (Infeksi Saluran Nafas Akut)



Gambar 4. Kegiatan sosialisasi cara menggunakan masker yang benar

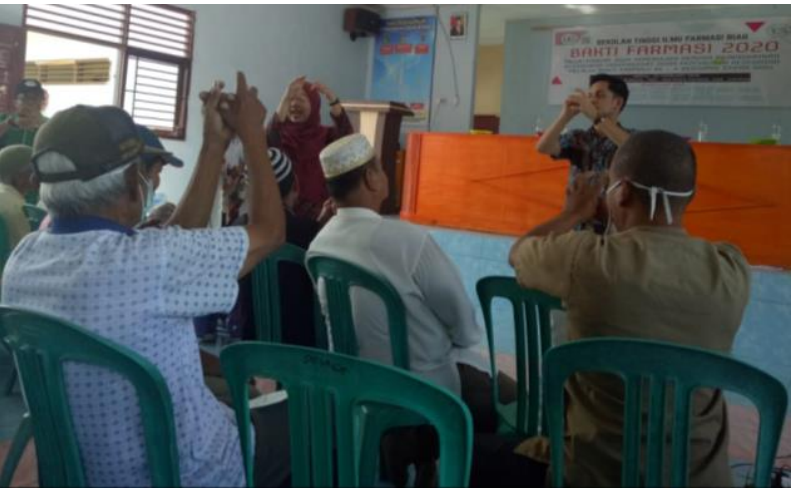

Gambar 5. Kegiatan sosialisasi cara mencuci tangan yang benar

Selain itu, juga disosialisasikan cara penggunaan masker (Gambar 4) dan cara mencuci tangan yang benar (Gambar 5) untuk pencegahan dan pengendalian penyakit ISPA yang dinilai memang sangat perlu dilakukan bagi masyarakat tersebut. ISPA merupakan penyakit yang banyak dijumpai di masyarakat Desa Gunung Bungsu, Kec. XIII Koto Kampar dinilai dari kunjungan pasien ISPA yang menempati urutan pertama dari pendataan yang telah dilakukan oleh Puskesmas. Kurangnya pengetahuan masyarakat mengenai ISPA meliputi gejala dan cara pecegahan terbukti dari berbagai pertanyaan yang diajukan oleh masyarakat setelah mendapatkan penjelasan dari Tim Pengabdian Masyarakat STIFAR untuk meningkatkan pemahaman mereka mengenai pencegahan dan pengendalian ISPA.

Informasi dari pemaparan yang telah diberikan dinilai sangat membantu masyarakat Desa Gunung Bungsu, Kec. XIII Koto Kampar akan ketidaktahuan tentang gejala, cara pencegahan dan pengendalian penyebaran Infeksi Saluran Nafas Akut (ISPA) serta cara menggunakan masker yang benar. Hal ini dibuktikan dari hasil kuisioner yang diisi oleh masyarakat setelah mendapatkan sosialisasi yang ditunjukkan pada Gambar 6 . 


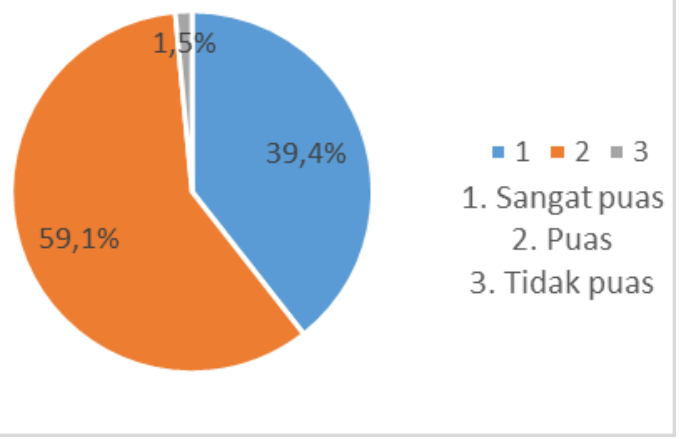

Gambar 6. Tingkat kepuasan masyarakat terhadap kejelasan apoteker/farmasis memberikan informasi mengenai ISPA dan cara menggunakan masker yang benar

Sejumlah 66 orang yang dimintai peniliannya mengenai kejelasan apoteker/farmasis memberikan informasi mengenai ISPA dan cara menggunakan masker yang benar, sekitar $39,4 \%$ menyatakan sangat puas terhadap informasi tersebut, dan 59,1\% menyatakan puas dan hanya $1,5 \%$ yang menyatakan tidak puas (Gambar 6).

Selain itu, dilakukan juga kuisioner penilaian kepuasan masyarakat dari pemberian pamflet sebagai media informasi tambahan dari sosialisasi yang telah diberikan langsung, sekitar $21 \%$ menyatakan sangat puas, $73 \%$ menyatakan puas dan hanya $6 \%$ menyatakan tidak puas (Gambar 7).

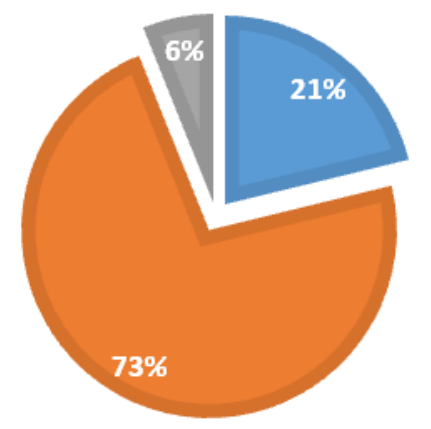

$$
\square 1 \square 2 \square 3
$$

1. SANGAT PUAS

2. PUAS

3. TIDAK PUAS

Gambar 7. Tingkat kepuasan masyarakat terhadap ketersediaan pamflet sebagai media informasi.

Berdasarkan hasil kuisioner yang diperoleh pada sosialisasi ini, dapat menyatakan bahwa masyarakat merasa puas dengan diadakan sosisalisasi dan mendapatkan pamflet sebagai media informasi tambahan untuk meningkatkan pemahaman mereka, dengan harapan mampu menerapkan dan mendampingi masyarakat lainnya terutama tentang bagaimana upaya mengetahui gejala sebagai bentuk deteksi dini jangkitan penyakit ISPA agar dapat segera ditangani dengan tepat dan mencegah penularan yang mungkin terjadi.

\section{Simpulan}

Pelaksanaan kegiatan pengabdian masyarakat di Desa Gunung Bungsu, Kec. XIII Koto Kampar berjalan dengan sangat baik sesuai target yang diharapkan. Hal ini dibuktikan dengan nilai persentase tingkat kepuasan tertinggi sekitar 39,4\% menyatakan sangat puas terhadap informasi tersebut, dan 59,1\% menyatakan puas dan hanya 1,5\% yang menyatakan tidak puas. Sedangkan hasil kuisioner penilaian kepuasan masyarakat terhadap pemberian pamflet sebagai media informasi tambahan, sekitar $21 \%$ menyatakan sangat puas, $73 \%$ menyatakan puas dan hanya $6 \%$ menyatakan tidak puas.

\section{Ucapan Terima Kasih}

Terima kasih kami ucapkan sebesar-besarnya kepada pihak Puskesmas Desa Gunung Bungsu, Kec. XIII Koto Kampar yang membantu kegiatan sosialisasi ini dan LPPM STIFAR RIAU.

\section{Daftar Pustaka}

Caruso T.J, Gwaltney J.M. (2005). Treatment of The Common Cold With echinacea: A structured review. Clin Infect Dis. 40: 807-10.

Departemen Kesehatan Republik Indonesia. (2009). Pedoman Pengendalian Penyakit Infeksi Saluran Pernafasan Akut, Direktorat Jendral Pengendalian Penyakit dan Penyehatan Lingkungan. Jakarta: Departemen Kesehatan RI.

Dewi, N.M.A.R., Puspitasari, C.E., \& Hanifa, N.I. (2020). Sosialisasi pencegahan penyakit infeksi kecacingan di wilayah Mataram. INDRA Jurnal Pengabdian kepada Masyarakat, 1(1), 1-4. doi:https://doi.org/10.29303/indra.v1i1.18

Direktorat Jenderal Pengendalian Penyakit dan Penyehatan Lingkungan. (2011). Pedoman Pengendalian Infeksi Saluran Pernapasan Akut. Jakarta: Kemenkes RI.

Kementerian Kesehatan Republik Indonesia. (2012). Pedoman Pengendalian Penyakit Infeksi Saluran Pernapasan. Jakarta: Departemen Kesehatan Republik Indonesia.

Kementerian Kesehatan RI. (2013). Riset Kesehatan Dasar 2013. Jakarta: Badan Penelitian dan Pengembangan Kesehatan. 
Maryunani A. (2012). Ilmu Kesehatan dalam Kebidanan. Jakarta: Trans Info Media.

Masriadi. (2017). Epidemiologi Penyakit Menular. Depok: Raja Grafindo Persada.

Sukarto R.C., Ismanto A.Y. and Karundeng M. (2016). Hubungan Peran Orang Tua Dalam Pencegahan ISPA Dengan Kekambuhan ISPA Pada Balita Di Puskesmas Bilalang Kota Kotamobagu, e-Journal Keperawatan, 4, 1-6.

WHO. (2007). Pencegahan dan Pengendalian Infeksi Saluran Pernapasan Akut (ISPA) Yang Cenderung Menjadi Epidemi dan Pandemi di Fasilitas Pelayanan Kesehatan. Pedoman Interim WHO. Alih Bahasa: Trust Indonesia. Jakarta.

Widoyono. (2011). Penyakit tropis. epidemologi, penularan, pencegahan, dan pemberantasannya. Jakarta: Erlangga. 